\title{
JAMU TRADISIONAL INDONESIA: TINGKATKAN IMUNITAS TUBUH SECARA ALAMI SELAMA PANDEMI
}

\section{TRADITIONAL INDONESIAN JAMU: NATURAL WAY TO BOOST IMMUNE SYSTEM DURING PANDEMIC}

\author{
Adristy Ratna Kusumo, Farrel Yumna Wiyoga, Haekal Putra Perdana, Izzatidiva \\ Khairunnisa, Raihan Ibadurrohman Suhandi, Shinta Sunja Prastika \\ ${ }^{1}$ Mahasiswa Kuliah Kerja Nyata BBM UNAIR 62 Lembaga Pengabdian Masyarakat, \\ Universitas Airlangga Kampus C UNAIR, Jl. Mulyorejo, Surabaya Jawa Timur, \\ Indonesia, 60115 \\ adristy.ratna.kusumo-2017@ff.unair.ac.id
}

\begin{abstract}
In the midst of a health crisis due to the COVID-19 pandemic that has not ended yet, traditional medicine is one of the alternative that can be used to break the chain of transmission and to maintain immunity. Jamu is a traditional herbal medicine that has been practiced for centuries in Indonesia to maintain our health. Jamu can be used for maintaining immunity to avoid virus from our body. Especially at this time, where a cure for a disease has not been found yet, people will return to use plants as an alternative treatment with various benefits. Plants that can be consumed and made into herbs for immune booster is curcuma, turmeric, and ginger. This project is educating people to understand the benefits of jamu and by sharing the tutorial video about steps to make jamu, hopefully people can try it at home to avoiding the spread of this virus.
\end{abstract}

Keywords: jamu, pandemic, immunity.

\section{abstrak}

Ditengah krisis kesehatan akibat adanya pandemi COVID-19 yang belum juga usai, pengobatan tradisional menjadi salah satu alternatif yang dapat digunakan masyarakat untuk memutus rantai penularan serta menjaga imunitas tubuh. Jamu merupakan obat herbal tradisional yang telah dipraktekkan selama berabad-abad di masyarakat Indonesia untuk menjaga kesehatan. Jamu dapat berfungsi untuk menjaga imunitas tubuh agar terhindar dari virus yang sedang merebak. Terutama disaat saat seperti ini, dimana belum ditemukannya obat untuk suatu penyakit, masyarakat akan kembali menggunakan tumbuhan sebagai alternatif pengobatan dengan manfaatnya yang beragam. Tanaman yang dapat dikonsumsi dan dibuat menjadi jamu untuk immune booster antara lain adalah temulawak, kunyit, dan jahe. Penyuluhan ini dilakukan agar masyarakat umum lebih memahami manfaat jamu dan dengan membuat serta menyebarluaskan video tutorial pembuatan jamu diharapkan masyarakat dapat mempraktekkannya dirumah untuk mencegah penularan virus ini.

Kata Kunci: jamu, pandemi, imunitas.

\section{PENDAHULUAN}

Dunia sedang menghadapi krisis kesehatan dan sosial-ekonomi global yang belum pernah terjadi sebelumnya yang dipicu oleh pandemi COVID-19. Penyakit dari kasus pertama yang dikonfirmasi oleh laboratorium tentang infeksi 2019-nCoV adalah pada 1 Desember 2019 di Wuhan, Cina. Pada 15 Juli 2020, ada 78.572 kasus Covid-19 yang dikonfirmasi di Indonesia, di mana 3.710 meninggal dan 37.636 orang pulih (Covid-19 impact and responses: Indonesia). COVID-19 memiliki masa inkubasi rata-rata 5,2 hari (interval kepercayaan 95\%, 4,1-7,0). Infeksinya akut tanpa status karier apa pun. Gejala biasanya dimulai dengan sindrom nonspesifik, termasuk demam, batuk kering, dan 
kelelahan. Beberapa sistem mungkin terlibat, termasuk pernapasan (batuk, napas pendek, sakit tenggorokan, rinore, hemoptisis, dan nyeri dada), gastrointestinal (diare, mual, dan muntah), muskuloskeletal (nyeri otot), dan neurologis (sakit kepala atau kebingungan). Tanda dan gejala yang lebih umum adalah demam (83\% -98\%), batuk (76\%-82\%), dan sesak napas (31\%-55\%). Ada sekitar 15\% dengan demam, batuk, dan napas pendek.

Di Indonesia, kehidupan jutaan anak-anak dan keluarga telah berubah. Lockdown dan penutupan berbagai sarana memengaruhi pendidikan, kesehatan mental, dan akses mereka ke layanan kesehatan dasar. Pertimbangan ekonomi selalu penting bagi pemerintah ketika mengambil tindakan apa pun, termasuk dalam perjuangan saat ini untuk mengatasi ancaman pandemi coronavirus. Oleh karena itu, daerah-daerah tertentu termasuk Jakarta sudah dalam masa transisi setelah 4 bulan lockdown, yang berarti bahwa pembatasan telah dilonggarkan untuk kegiatan-kegiatan di lembaga-lembaga pendidikan, urusan agama, pekerjaan, area publik, pertemuan sosial dan tujuan budaya. Mal sudah buka, tetapi dengan langkah-langkah keamanan yang ketat dan waktu operasi yang terbatas.

Upaya penelitian yang kuat saat ini sedang dilakukan untuk mengembangkan vaksin melawan Covid-19. Meskipun belum ada obat atau pengobatan khusus untuk COVID19, ada beberapa hal yang dapat Anda lakukan untuk memperkuat sistem kekebalan tubuh Anda terhadap virus corona. Terutama dimasa new normal seperti sekarang, kehidupan harus terus berjalan sedangkan virus juga tidak berhenti berterbangan. Sehingga mempertahankan kekebalan atau sistem kekebalan adalah salah satu cara untuk menghindari infeksi virus dan penyakit, termasuk Covid-19. Organisasi Kesehatan Dunia (WHO) menyambut baik berbagai inovasi di seluruh dunia termasuk penggunaan kembali obat-obatan, obat-obatan tradisional dan mengembangkan terapi baru dalam mencari pengobatan potensial untuk COVID-19. Ada banyak cara untuk tetap sehat dan memperkuat sistem kekebalan tubuh selama pandemi ini, kekebalan tidak dapat dibangun dalam sehari, tetapi kabar baiknya adalah bahwa makanan dan minuman yang seimbang dan aktif secara fisik dan mental biasanya cukup untuk menjaga sistem kekebalan tubuh Anda dalam keadaan sehat.

Jamu mungkin dapat menjadi salah satu pilihan untuk memperkuat sistem imun tubuh seseorang. Jamu adalah obat herbal tradisional Indonesia yang telah dipraktekkan selama berabad-abad di masyarakat Indonesia untuk menjaga kesehatan dan mengobati penyakit. Meskipun sudah banyak obat-obatan modern, jamu masih sangat populer di daerah pedesaan maupun perkotaan (Elfahmi et al., 2014). Terutama disaat saat seperti ini, dimana belum ditemukannya obat untuk suatu penyakit, masyarakat akan kembali menggunakan tumbuhan sebagai alternatif pengobatan dengan manfaatnya yang beragam. Selain itu dengan harga yang murah dan bahan baku yang mudah ditemukan, jamu dapat dibuat dan dikonsumsi sendiri di rumah.

Tanaman yang dapat dikonsumsi dan dibuat menjadi jamu untuk immune booster antara lain adalah temulawak, kunyit, dan jahe. Selain bahan utama tersebut dapat juga ditambahkan bahan lain untuk menambah rasa dan memberi aroma yang menggugah selera seperti kayu manis, serai, dan gula aren. 
Temulawak atau Curcuma xanthorrhiza Roxb merupakan tanaman yang sering digunakan sebagai obat-obatan yang tergolong dalam suku temu- temuan (Zingiberaceae). Salah satu kandungan terbanyak yang dimiliki tumbuhan temulawak ialah pati, pati temulawak mengandung kurkuminoid yang membantu proses metabolisme dan fisiologis organ badan. Penggunaan temulawak dalam pengobatan tradisional banyak digunakan dalam pengobatan gangguan pencernaan, sakit kuning, keputihan, meningkatkan daya tahan tubuh serta menjaga kesehatan (Aldizal et al., 2019). Jahe (Zingiber officinale) merupakan tanaman rempah yang berasal dari Asia Selatan, dan sekarang telah tersebar ke seluruh dunia. Jahe dimanfaatkan sebagai bahan obat herbal karena mengandung minyak atsiri dengan senyawa kimia aktif, yang berkhasiat dalam mencegah dan mengobati berbagai penyakit (Goulart, 1995; Reader's Digest, 2004; Sudewo,2006; Santoso, 2008). Senyawa kimia aktif yang juga terkandung dalam jahe yang bersifat anti-inflamasi dan antioksidan, adalah gingerol, beta-caroten, capsaicin, asam cafeic, curcumin dan salisilat. (Yuan Shan \& Iskandar, 2018).

Kunyit, Curcuma longa L. (Zingiberaceae) adalah tanaman tropis yang banyak terdapat di benua Asia. Dalam sejarah perobatan rakyat India, kunyit dianggapkan sebagai bahan antibiotik yang terbaik sementara pada masa yang sama kunyit juga digunakan untuk memudahkan proses pencernaan dan memperbaiki perjalanan usus. Dari ketiga bahan diatas diketahui mengandung senyawa kurkumin yang memiliki banyak sekali manfaat seperti : antioksidan, antiinflamasi, antibakteri, dan antivirus yang sangat cocok apabila digunakan untuk meningkatkan imunitas agar tetap sehat dikala pandemi seperti saat ini (Redi Aryanta, 2019).

Menurut Prof. Dr. Mangestuti Agil, MS, Apt. salah satu guru besar di Fakultas Farmasi Universitas Airlangga pada artikel yang dipublish oleh The Jakarta Post "Kunyit, misalnya, bermanfaat untuk meningkatkan kekebalan tubuh kita. Ini juga berfungsi sebagai antioksidan dan antimikroba," menambahkan bahwa jahe juga dikenal sebagai penguat kekebalan tubuh dan temulawak bermanfaat dalam menjaga kesehatan hati. Prof. Dr. Mangestuti juga menambahkan bahwa mengkonsumsi tanaman tersebut dalam bentuk jamu secara teratur berpotensi mencegah penularan berbagai mikroba, termasuk virus dan bakteri.

Selain konsumsi Jamu, menambahkan konsumsi suplemen juga disarankan jika Anda merasa membutuhkan. Sementara itu, orang dengan aktivitas fisik berlebihan, orang yang dipaksa bekerja di luar rumah, dan orang dengan sistem kekebalan tubuh yang lemah seperti orang dengan komorbiditas sangat dianjurkan untuk mengkonsumsi imunostimulan. Mengelola stres juga penting, karena stres memengaruhi kekebalan tubuh.

\section{METODE PENGABDIAN MASYARAKAT}

Pelaksanaan pengabdian kepada masyarakat dilakukan melalui tiga tahap, yaitu membuat video tutorial yang berisi penjelasan tentang bahan-bahan untuk membuat jamu serta cara pembuatannya, membagikan video tutorial tersebut lewat akun sosial media Instagram, dan membagikan jamu untuk masyarakat sekitar.

Pada tahap pertama, kami mencari terlebih dahulu bahan-bahan yang dibutuhkan untuk membuat jamu. Pada video tutorial ini, kami menggunakan bahan utama yang sudah 
menjadi serbuk dan beberapa bahan pelengkap untuk menambah rasa dan memberi aroma yang menggugah selera. Setelah mendapat semua bahannya, kami melakukan take video edukasi mengenai bahan-bahan apa saja yang dibutuhkan untuk membuat jamu, menjelaskan secara singkat tentang manfaat setiap bahan dan juga mempraktekkan cara pembuatan jamu itu sendiri.

Tahap selanjutnya yaitu membagikan video tutorial. Hasil yang diperoleh dari pembuatan video di bagikan secara daring melalui akun Instagram kelompok $272 \mathrm{KKN}$ BBM Mandiri ke- 62 Universitas Airlangga. Video pembuatan jamu dibagikan secara daring karena kondisi saat ini yang masih dalam masa pandemi sehingga tidak memungkinkan untuk bertatap muka. Pembagian video secara daring juga sangat membantu untuk mempercepat sebaran video dan dapat mencakup kalangan luas.

Tahap terakhir adalah membagikan jamu yang telah dibuat di sekitar Perumahan Taman Royal, kecamatan Cipondoh, Kota Tangerang. Pembagian jamu ini sebagai bentuk bantuan fisik dari kelompok KKN 272 periode 62 Universitas Airlangga kepada masyarakat sekitar dan diharapkan juga masyarakat dapat meningkatkan imunitas mereka, salah satunya dengan cara mengonsumsi jamu.

\section{HASIL DAN PEMBAHASAN}

Jamu adalah minuman herbal tradisional khas Indonesia yang masih ada sampai zaman obat modern sekarang ini. Bahan-bahan jamu berasal dari tumbuh-tumbuhan yang langsung diperoleh dari alam sehingga mudah didapatkan dan jamu tidak mengandung kimia sintetik sehingga efek sampingnya tidak terlalu besar. Berikut adalah tabel yang berisi bahan-bahan utama dari jamu serta manfaatnya:

Tabel 1. Kandungan dan Manfaat dari Bahan-Bahan Jamu

\begin{tabular}{cllc}
\hline No & Bahan-bahan & Kandungan & Keterangan \\
\hline 1 & $\begin{array}{l}\text { Jahe (Zingiber } \\
\text { Officinale) }\end{array}$ & $\begin{array}{l}\text { Gingerol, Beta-Caroten, } \\
\text { ipsaicin, Asam Cafeic, } \\
\text { Curcumin, Salicilat }\end{array}$ & $\begin{array}{c}\text { Mengandung senyawa kimia aktif yang } \\
\text { bersifat }\end{array}$ \\
2 & $\begin{array}{l}\text { Kunyit (Curcuma } \\
\text { Longa L) }\end{array}$ & Curcumin & $\begin{array}{c}\text { inflamasi dan antioksidan } \\
\text { Memudahkan proses pencernaan, }\end{array}$ \\
3 & $\begin{array}{c}\text { Temulawak (Curcuma } \\
\text { Xanthorrhiza Roxb) }\end{array}$ & $\begin{array}{c}\text { Curcumin, Flavonoid, } \\
\text { Minyak Atsiri }\end{array}$ & $\begin{array}{c}\text { inflamasi, anti bakteri, antivirus yang } \\
\text { berfungsi meningkatkan imunitas, }\end{array}$ \\
& & & $\begin{array}{c}\text { Membantu proses metabolisme, } \\
\text { menyembuhkan radang, dan mengharumkan. }\end{array}$ \\
\hline
\end{tabular}

Selain bahan-bahan utama yang terdapat pada Tabel 1. kita juga dapat menambahkan bahan lain seperti gula aren untuk menambah rasa manis pada jamu, jeruk nipis untuk menambah sedikit rasa asam, kayu manis dan serai agar jamu terasa harum, serta garam untuk menetralisir rasa. Semua bahan-bahan yang telah disebutkan dapat diperoleh dipasar terdekat. Kita dapat menggunakan bahan-bahan tersebut baik berupa parutan maupun serbuk yang praktis didapatkan dipasaran. 
Mengonsumsi jamu cukup penting untuk menjaga imunitas dikala pandemi COVID-19. Untuk mengedukasi masyarakat, kami membuat video tutorial pembuatan jamu yang telah dibagikan lewat akun Instagram kelompok 272 KKN BBM Mandiri ke- 62 Universitas Airlangga (@kknunair.272) pada tanggal 10 Juli dan sudah mencapai 582 kali tayang per 24 Juli 2020. Tidak terdapat kendala dalam pembuatan video tutorial maupun penyebaran video.

Selain itu, kami juga membagikan jamu yang telah dibuat ke masyarakat di sekitar Perumahan Taman Royal, kecamatan Cipondoh, Kota Tangerang sebagai bukti fisik dari kegiatan KKN Kelompok 272 periode 62 Universitas Airlangga.

Dokumentasi kegiatan kami terdapat pada Gambar1-4 berikut:

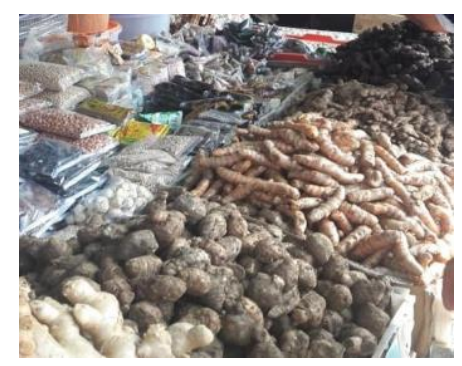

Gambar 1. Membeli bahan-bahan untuk membuat jamu

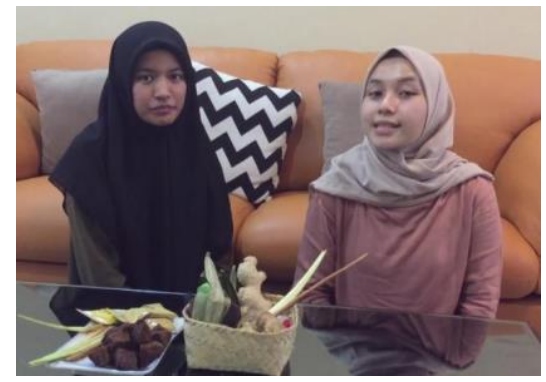

\section{Gambar 2. Pembuatan video tutorial}

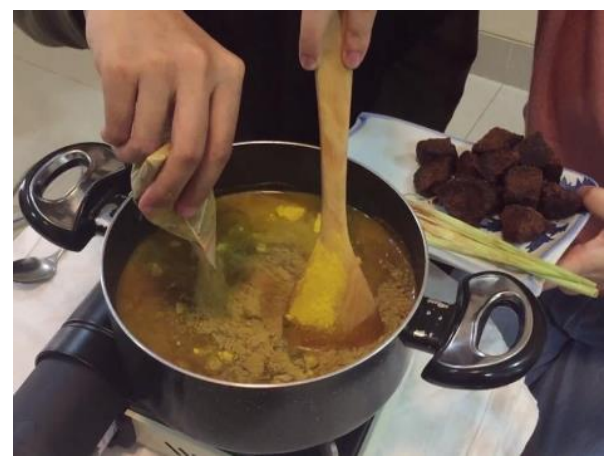

Gambar 3. Proses pembuatan jamu 


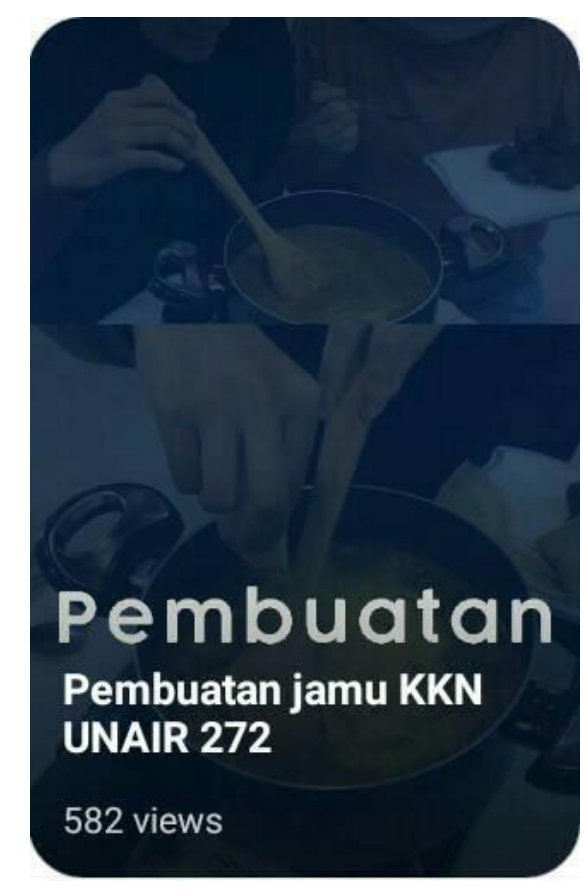

\section{Gambar 4. Membagikan video tutorial}

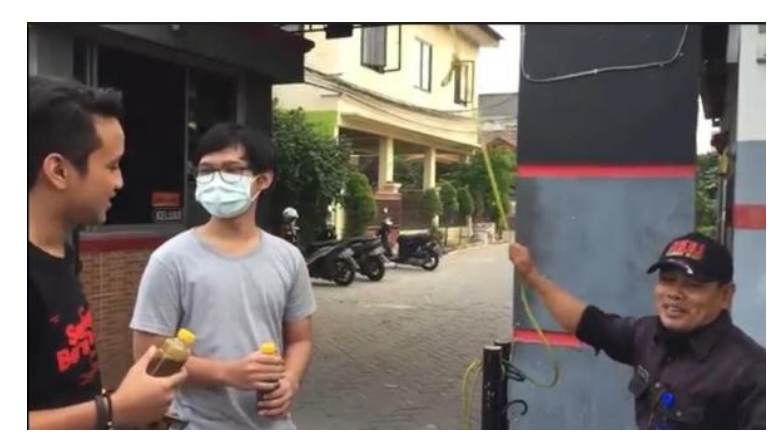

Gambar 5. Membagikan jamu

\section{PENUTUP}

\section{Simpulan}

Kegiatan pengabdian masyarakat mengenai edukasi dan sosialisasi tentang tata cara pembuatan jamu serta pentingnya manfaat jamu melalui channel youtube dan instagram diharapkan dapat menjadi alternatif sekaligus referensi masyarakat terkait pentingnya menjaga imunitas ditengah pandemi COVID-19 yang obatnya belum juga ditemukan. Dengan pengabdian tersebut diharapkan timbul pemikiran baru di masyarakat yaitu (a) Pengetahuan tentang pentingnya menjaga imunitas dengan minuman herbal dikala pandemi. Selain itu (b) Menambah pengetahuan tentang cara membuat minuman herbal yang praktis dan tentunya dapat dikerjakan dirumah.

\section{Saran}

Setelah pengabdian dilaksanakan, diharapkan pemerintah maupun masyarakat selalu meningkatkan kepedulian tentang edukasi yang berkaitan dengan pencegahan 
penularan virus COVID-19. Pemerintah diharapkan dapat selalu memberikan edukasi tentang berbagai macam cara mencegah penyebaran virus ini dan juga masyarakat dapat saling bertukar informasi mengenai pengetahuan yang berkaitan dengan pencehgahan tersebut.

\section{DAFTAR PUSTAKA}

Aldizal, R., Rizkio, M., Perdana, F., Suci, F., Galuh, V., Putri, A., Rina, A., Cahyani, N. D., Yanti, R., \& Khendri, F. (2019). Review: Tanaman Temulawak (Curcuma xanthorrhiza Roxb) sebagai Obat Tradisional. Jurnal Ilmiah Farmako Bahari. https://doi.org/2087-0337

Covid-19 impact and responses: Indonesia. (n.d.). Retrieved July 23, 2020, from https://www.fairwear.org/covid-19-dossier/worker-engagement-andmonitoring/country-specific-guidance/indonesia/

Elfahmi, Woerdenbag, H. J., \& Kayser, O. (2014). Jamu: Indonesian traditional herbal medicine towards rational phytopharmacological use. In Journal of Herbal Medicine. https://doi.org/10.1016/j.hermed.2014.01.002

Organization, W. H. (2020, May 4). WHO supports scientifically-proven traditional medicine. Retrieved July 23,2020, from https://www.afro.who.int/news/whosupports-scientifically-proven-traditional-medicine

Redi Aryanta, I. W. (2019). MANFAAT JAHE UNTUK KESEHATAN. Widya Kesehatan. https://doi.org/10.32795/widyakesehatan.v1i2.463

UNICEF. (n.d.). Novel coronavirus (COVID-19) outbreak: What you should know . Retrieved July 23, 2020, from https://www.unicef.org/indonesia/coronavirus

Yuan Shan, C., \& Iskandar, Y. (2018). Studi Kandungan Kimia Dan Aktivitas Farmakologi Tanaman Kunyit (Curcuma longa L.). Pharmacia. 